\title{
Consumerism in American Society and the Role of Government
}

\author{
Fred Bedell \\ Del G Publishing, Fountain Hills, AZ, USA \\ Email: bedelld@aol.com
}

Received 8 September 2014; revised 18 October 2014; accepted 22 November 2014

Copyright (C) 2014 by author and OALib.

This work is licensed under the Creative Commons Attribution International License (CC BY). http://creativecommons.org/licenses/by/4.0/

(c) (i) Open Access

\section{Abstract}

This essay speaks to the fact that the United States is a consumptive society, as we are dependent on producers to provide the goods and services necessary to maintain our daily living requirements. It addresses a correlation between historical policies and presents events and practices that continue to undermine public policies that benefit the consumer. Most importantly, the role of government is to provide health and safety for the population and protect it from a corrupt political system that places us at risk for the food we eat, the water we drink, and the air we breathe. Mike Leibovich in his book "This Town" refers to Washington DC as the "Gilded Capital," because in his view there is an incestuous relationship among the law firms, politicians, media, and lobbying firms whose agendas are not often in the public's interest. We will examine in detail three areas-food, health care, and the counterfeiting of goods-that are of paramount interest to the nation and examples of the point of the essay.

\section{Keywords}

Consumerism, Role of Government, Corrupt System and Politicians, Health, Generically Modified Foods (GM), Affordable Care Act (ACA), Consumptive Society, Corporate Influence over the Legislature, Health Care Reform, Counterfeit Goods

\section{Subject Areas: Consumer Behavior, Social Issues and Public Policy}

\section{Overview}

The role of government in American life has become a major issue in political circles. The current debate in this area focuses around the view that government is too big and the major problem in the country's economic malaise.

Consumers are at risk for the air we breathe, the water we drink, and the food we eat, but the government has the responsibility for the health and safety of the populace. 
The purpose of this essay is to present a correlation between historical public policies and their current status, which in most cases the average consumer is unaware and the consumer is not the beneficiary.

The essay will examine the elements of consumerism, how it is the driver of the economy, and the role of corporations and government in this scenario. We will focus on three particular areas to illustrate our intentions—-food production, health care, and the counterfeiting of goods.

\section{Consumptive Society}

Consumption is the process by which goods and services are put to final use by people [1]. In reality, the economy is driven by the demand for goods and services from the public. Corporations are formed to manufacture the products and provide the services to meet these demands.

In Vance Packard's book, “The Waste Makers" (circa 1960), he examined the manufacturing production practice at that time, which was to replace parts rather than repair them [2]. He characterized this policy as "Planned Obsolescence." This policy purposely had goods made that were shoddy and with a limited life, so that customers had to replace them.

Subsequently, he changed his theory to one of "Planned Obsolescence of Desirability," which is the design of fashionable items to induce people to purchase new ones even though the old ones worked fine, which is fueled in large part by immediate gratification. This trend is largely responsible for keeping the economy going [3].

In Boston University Professor Andrew Bacevich’s book "The Limits of Power," he suggests that we as a nation are a consumptive society, and that we have become accustomed to the luxury of having cheap goods, easy credit, and cheap oil (energy) [4]. This mindset has driven our economic and foreign policies for many decades. Thomas Friedman in his column in the New York Times characterizes this mindset a Diet Coke Culture, "as we want the sweetness without the calories, the consumption without the savings, and the safety net without the taxes [5].” This theory will be highlighted throughout the essay and particularly in the section on counterfeiting goods.

\section{Corporate Behavior}

We have acknowledged how consumers seek to satisfy their wants and needs, and now we will examine how corporations pursue their interests. Corporations' major interests are to satisfy their shareholders, which in some cases may not be in the best interests of consumers. This implication is verified by the transfer of our manufacturing base abroad to acquire cheap labor. It is the prime example of corporate initiatives for profit, having a negative impact on job availability in the United States.

In my opinion, this mindset has driven the policies and practices of corporations and corrupt politicians to pursue their own interests, whether for corporate shareholders or the politicians themselves, rather than the public for whom they were elected to serve. By corrupt politicians, I mean that the system of government and the election process has corrupted them. In today's political climate, an individual must raise vast amounts of money for his/her campaigns in order to be elected to public office. To acquire these funds, politicians receive donations from corporations and individuals, making them beholden to these benefactors [6].

The question that comes to the forefront is how politicians use the government for their special interests, rather than for the people they represent. This observation is the central theme in Mark Leibovich's book entitled "This Town [7]." Bill Moyers interviewed Mr. Leibovich on his TV Journal telecast where he stated, "We are close to losing our democracy to the mercenary class as a result of the predators in Washington DC, who are close to monopolizing control of the government." The major political implication for working people is that the wealthy can buy the political system that serves their interests.

Moreover, the central theme that resonates in the discourse around public policy is the role of government, particularly in the area of regulation. Surely, as noted earlier, government is responsible for the health and safety of the populace. Let's try to put these policies and practices into historical perspective.

\section{The Commons}

“This Land is Our Land,” a documentary presented by David Bollier on Link Television (2012), depicts the struggle between the marketplace and the commons [8].

The commons is defined by Mr. Bollier in the following context, "The commons consists of all things we as a 
society collectively own and have an obligation to pass on to future generations undiminished, e.g., air, water, coastal areas, and national parks. Some states name themselves commonwealths with the idea that people take responsibility for these shared resources and are entitled to use them."

Enclosing the commons (privatization) by corporations has become the vehicle to provide services that were heretofore provided by the government under the premise that it was more cost effective (cheaper and more efficient). The free market continues to enclose the commons and privatize services and natural resources at the expense of the many for the gains of the few.

\section{Corporate Influence over the Legislature}

In Robert Kennedy III's guest appearance on the Tavis Smiley Telecast (2013), he indicated that if one looks at the historical perspective when corporations controlled the legislature, in some states the public had little leverage, moving President Teddy Roosevelt to take action to curb their influence [9]. He characterized corporations as "Malefactors of Great Wealth" and initiated the Sherman Anti-Trust Act that broke up the sugar, oil, and steel trusts. In addition, he pushed through laws such as the following:

- Required states to elect senators, rather than appointments made by the state legislature.

- Enacted laws that prohibited corporations from contributing to federal officials and candidates for federal office.

- Instituted the Public Information Act (Fairness Doctrine) that stated that the airways belonged to the public, and broadcasts were to be used to inform the public. In 1980, President Ronald Reagan repealed the "Fairness Doctrine," which was viewed by some as a reward to the Christian right who helped his election.

In 2010, the Supreme Court repealed the 100-year-old law that forbade corporations to contribute to federal officials and candidates for federal office, the "Citizens United Act [10]."

The American Legislative Exchange Council (ALEC) is a nationwide consortium of elected state legislators who work side-by-side with American corporations. As stated on Bill Moyers TV Journal, their mission is to change the country by changing its laws. It creates model legislation, which are pro-corporate laws that its members push in state houses across the country [11].

Needless to say, ALEC is one of the most powerful and influential organizations in American politics. So how do we define the purpose of government? "The mission of government is to protect and empower all of the populace on an equal basis through the use of the public (commons) as resources for the benefit of life for all.” Politics is a system that works for the people as espoused by George Lakoff in his "Little Blue Book [12]."

To establish a correlation between historical public policies and the current status, noting that the consumer is often not the beneficiary (which is the intent of this essay), we will discuss three areas-health, food, and counterfeiting goods. Each is a major item of concern to the country's wellbeing in the context of corporate vs. public interest, the lack of resources and regulations, and how politicians are influenced by a corrupt political system (which has a major impact on the financial and political system in the United States).

\section{Health and Safety}

\subsection{Overview}

In this section of the essay, we will use examples of producer's practices in collusion with elected or appointed public officials and the funneling of enormous amounts of money in initiatives for their self-interests, placing consumers (taxpayers) between a rock and a hard place.

Moreover, policies and practices by corporations in concert with the federal government come into question regarding the purposes of federal agencies that were created to protect and benefit the consumer. In particular, the Food and Drug Administration (FDA) is a federal agency of the United States Department of Health and Human Services, which is responsible for protecting and promoting public health through the regulation and supervision of food safety and other consumer products [13].

Incidentally, in 2009 the Obama administration appointed former Monsanto Vice President and Head Lobbyist Michael Taylor as the Deputy Commissioner for the Food and Drug Administration, the board tasked with regulating Taylor's own industry [13]. The fox guarding the chicken coop seems to be an appropriate analogy in this case.

In this section, we will focus on food production and present observations as how corporations are modifying 
specific foods.

\subsection{Food}

The land is for all living things. It, above all, nourishes all of us. In the Native American culture, a relationship with God is experienced as a relationship with all creation, e.g., rocks, trees, mountains, and everything that is visible and must be respected. They view the land with great respect and honor all living breathing entities such as father sun, mother moon, and sister earth. The animals were their kinsmen. Their environment was respected, not exploited [13].

Wendell Berry, a poet and prophet, was interviewed on the Bill Moyer's TV Journal telecast on 10/4/13 [14]. He spoke about the land, which he referenced in his book, "The Reselling of America." His main point was the defense of the earth, as he sees it being desecrated and despoiled by such policies as the blowing off of mountain tops, resulting in the poisoning of streams and rivers.

He questioned how these situations happen and has concluded that "people with money are more powerful than the ordinary citizen." No surprise here. His major concern is the disaster of the land, as we have a dependence on mechanical power and toxic chemicals. He states, "It is a disaster to be governed by corporations and corrupted politicians who should represent the people and not be bought by moneyed interests."

\subsection{Genetically Modified Foods (GM)}

A controversy exists today around the labeling of genetically modified foods. Food-producing organizations resist the labeling of their products, whereas consumer groups take the position that these products should be labeled [13].

\subsection{Definitions}

Genetically modified foods (GM) are foods derived from organisms whose genetic material (DNA) has been modified in a way that does not occur naturally, e.g., through the introduction of a gene from a different organism. Most GM foods stem from plants [13].

\subsection{Issue}

The GM foods controversy is a dispute over the foods and other goods derived from genetically modified crops (instead of conventional or organic crops) and whether the GM crops should be labeled. The groups involved in this controversy are consumers, biotechnology companies, government agencies (regulatory), non-governmental agencies, and scientists. Some advocacy groups such as Greenpeace and The World Life Fund feel that GM foods have not been adequately identified and managed in addition to the objectivity of regulatory authorities [13].

In a recent article in the Wall Street Journal, "Meet Mr. Frankenfood," written by Kate Bachelder, reported an interview with Brett Begemann, the president of Monsanto Food Products [15].

The article opens with the following statements, "Opponents claim that genetic modification poses health risks, and groups such as the non-GMO project 'Just Label It' and others want labels required on all foods containing GM ingredients. Vermont passed a GM labeling bill in May, and Oregon and Colorado will hold referendums in November. Companies including Ben and Jerry's and Chipotle Mexican Grill say they are removing GM ingredients from their foods, and General Mills recently made Cheerios cereal GMO free.”

\subsection{Rebuttal}

Brett Begemann, President of Monsanto, explains why GM foods are not only safe but more cost effective to produce than conventionally grown foods, and he offers the following statement to support his position:

“Farmers have genetically improved crops through breeding, choosing the best 'mom and pop' plants, as an example, to make a bitter tasting cabbage into something more palatable. As a result of biotechnology, seeds can better tolerate drought and resist pests. In 2011, farmers earned \$19.8 billion added economic benefit from GM crops according to a 2013 report by the UK-based PG Economics. GM seeds are more resilient, yield more crops on less land, and require less labor.

The major issue is that the public is wary of purchasing GM products, as they feel the products are unsafe, 
and food corporations feel the labeling of these products will have a negative impact on sales."

Mr. Begemann continues, "There exists a federal labeling of products, ergo, "organic products."

Even though the federal labeling exists, Monsanto is spending big money to fight the labeling movement, particularly in California where it spent \$8 million dollars to defeat a labeling initiative on the California ballot in 2012 [15].

This issue is ongoing, and we will have to wait to see results.

\section{Health Care}

\subsection{Overview}

This historical overview is detailed in a brief chronological history of health care reform. This section of the essay emphasizes the past practices and policies by stakeholders in the insurance industry and members of the medical profession-in concert with politicians who continued to undermine public policies that benefit the consumer. An article entitled "Health Care Reform: From Truman to Obama" chronicles health care initiatives over 65 years-from Truman to Obama. The article was written by Jerry W. Taylor and J. D. Stites and published by Becker’s Hospital Review, February 11, 2014 [16].

\subsection{Harry S. Truman's Proposal for a Health Care Plan, November 19, 1945 (Harry S. Truman Library)}

On November 19, 1945, Harry S. Truman sent a presidential message to the US Congress proposing a new national health care program. He argued that, "The federal government should play a role in health care," saying "the health of American children, like education, should be recognized as a definite responsibility." A chief aim of the plan was to ensure that all communities, regardless of size or income levels, had access to doctors and hospitals. The American Medical Association initiated an attack against the bill, referring to it as "socialized medicine.” Subsequently, support for the bill was abandoned [13].

\subsection{The Eisenhower Administration (1953-1961)}

The Eisenhower Administration supported only limited health care proposals. In 1956, the "Military Medicare Program” was enacted, providing payments for health care services for military dependents [13].

\subsection{The Kennedy Administration (1961-1963)}

The Kennedy Administration pursued a modest form of health care coverage, different from what was proposed by President Truman. The Kennedy Administration supported the King-Anderson Bill under which health insurance coverage would be limited to those over 65 years of age and older and would be part of the Social Benefits package. Again, the American Medical Association (AMA), with the help of certain members of Congress, opposed the bill [13].

\subsection{The Johnson Administration (1963-1969)}

Under the Johnson Administration, legislation establishing the Medicare and Medicaid programs was passed, covering people 65 years and older, the poor, blind, and disabled [13].

\subsection{The Nixon Administration (1969-1974)}

In 1971, the Nixon Administration proposed the National Health Insurance Standard Act, which called for government-prescribed, minimal levels of insurance coverage. This insurance coverage was mandated for employees and financed by the payment of premiums by employees and employers. The plan would maintain competition between private insurers and expand coverage. Nixon was successful in gaining passage of the National Health Maintenance Act of 1973, which laid some of the groundwork for managed care [13].

\subsection{The Ford Administration (1974-1977)}

The National Health Planning and Resources Development Act of 1974 was an effort to rein in health care costs 
caused by the unrestrained and federally incentivized growth of health care facilities [13].

\subsection{The Carter Administration (1977-1981)}

During Jimmy Carter's campaign for president, he called for national health care insurance with universal coverage. After elected, he worked on legislation to achieve that goal, which came to naught [13].

\subsection{The Regan Administration (1981-1989)}

During the Regan Administration, several new laws were enacted that were aimed primarily at reducing growth in federal spending on health care and improving efficiencies with limited effort [13].

\subsection{The George H. W. Bush Administration (1989-1993)}

President Bush inherited a political catastrophe in the Medicare Catastrophic Act of 1988. There was widespread disappointment over the level of expanded benefits and a strong resentment over paying higher premiums and taxes to fund it, leading to a senior revolt against the Act [13].

\subsection{The Clinton Administration (1993-2001)}

President Clinton appointed his wife, First Lady Hillary Clinton, to head a task force proposing major health care reform with affordable health insurance through managed competition. The concept was sent to Congress but never saw the light of day for political reasons [13].

\subsection{The George W. Bush Administration (2001-2009)}

Under President Bush, the Medicare Drug Improvement and Modernization Act of 2003 made significant changes to the Medicare Program, providing coverage for prescription drug coverage-Medicare Part D [13].

\subsection{The Obama Administration (2009-Present)}

Under the Obama Administration, the quest for a universal health insurance was finally realized. After 65 years of political machinations and stakeholder opposition, the Affordable Health Care Act (ACA) was passed.

\subsection{The Affordable Care Act ("Obamacare")}

\subsubsection{Definition and Goals}

The Affordable Care Act (ACA), commonly referred to as “Obamacare” (ACA HR 3962), was a bill crafted by the United States House of Representatives in November 2009.

The President's health plan is designed to give hardworking, middle-class families the security they deserve. The ACA forces insurance companies to play by the rules, prohibiting them from discriminating against anyone with a pre-existing condition, dropping their coverage if they get sick, restricting excessive billing, and putting limits on lifetime benefits [13].

Before the ACA was enacted, most insurers could raise premiums without any explanation and spend much of patients' premium dollars on administration costs and profits. Under the new law, patients have more rights and protections.

\subsubsection{Highlights of the Affordable Care Act}

- Prohibits health insurers from refusing coverage based on patients' medical histories.

- Prohibits health insurers from charging different rates based on patients' medical histories or gender.

- Repeals insurance companies' exemption from anti-trust laws.

- Establishes minimum standards for qualified health budget plans.

- Requires most employers to provide coverage for their workers.

- Provides subsidies to low- and middle-income Americans to help buy insurance.

- Establishes health insurance places to allow those who want individual or family health insurance coverage to select and sign up for coverage ("Getting Ready for the Affordable Health Care Act," by Debra Gilbert, 
Arizona Republic newspaper) [17]. For more detailed information, refer to the Act.

\subsubsection{Politics}

A group of elected politicians against the ACA is trying to amend it, defund it, and eventually repeal it. Health insurance companies put a lot of money into the Chamber of Commerce to lobby against the bill. This was viewed as a shell, as the insurance companies were behind the funding of this initiative so they would not be exposed per law professor Heather Gergen on Bill Moyers Telecast [18]. An old adage applies here: “You can’t evaluate the message if you don't know the messenger."

Most importantly, The ACA is the law, as it was passed by Congress, signed by the president, and affirmed by the Supreme Court. Wouldn't a rational person think that the political body should be working to improve the Act and not work against it?

\section{Going Forward}

Even though the rollout of the ACA had its difficulties, it is succeeding. In Jo Craven McGinty's article, "For Health Law's Vitals, Look Beyond Sign-ups," in the Wall Street Journal, she says, "The enrollments have succeeded beyond expectations [19]." She began the article by indicating that eight million people, as of the publication of the article, had signed up for the program, which the president declared as successful.

Moreover, "In most respects the republican revolt against the ACA for all its sound and fury has failed to impede the law." So says Maria Bustillos in her article "Easy Chair, Fill in the Gaps," published in Harper’s Magazine [20].

Obviously, problems still exist with the law, which certainly requires adjustments. Our lawmakers should focus on for the good of the populace as opposed to being obstructionists.

In a New York Times magazine in 2014, an article written by Adam Davidson, "Who is Betting on Obamacare" states, "The crusade to sign up Americans for the Act is getting all the attention, but behind the scenes investors are seeing the dollar signs [21]." Capitalism at its best.

The article speaks to the initiatives taken by large health care businesses, insurance companies, for instance, and hospital chains that have poured abundant resources into preparation for millions of new customers. In general, investors have shied away from threats to repeal or at least revise the law.

Another view of the law was expressed by Elizabeth Fowler, a former staff member for Senator Max Baucus and a chief architect of the ACA. She states that, "One of the goals of the act was to find ways to reduce the rate of growth in health care spending, as everyone was focused on coverage, and the changes in the law are designed to address costs that could be bigger an a longer lasting change.”One would think that the politicians who are opposed to the law should reexamine it. It would appear from the evidence that exists that the law is a "win-win" for all parties concerned.

\section{Counterfeiting Goods}

"The Counterfeit Culture," a television program aired on Link TV on October 11, 2014, identified the practice of illegal copying of clothing, electrical products, car and aviation parts, pharmaceuticals, computer parts, etc. [22]. The consumer's quest for cheap goods is the driver for demand, which fosters supply. Whether it is legal or illegal, morally right or wrong, is of little consequence.

Per Link TV, counterfeit goods account for one-fifth of the world's economy- $\$ 700$ billion a year. Counterfeiting is a huge, interconnected enterprise, as the world does business in a global fashion (globalization). International barriers have changed with the ability to purchase on the Internet, a major avenue of revenue. Capitalism is exported around the world, but exporting capitalism without also exporting the constraints that make capitalism "for good" provides poor outcomes.

Intellectual property theft and counterfeiting not only rob profit from legitimate manufactures but also put consumer's health and safety at risk The selling of counterfeit medicines have caused illness and deaths. The majority of our drugs are processed abroad; even the supply of aspirin is no longer made in the US. Most startling is that medicines are copied with little regard for the health and safety of the consumer, as profit is the motive. Medical devices, computer chips, auto parts, and airplane parts are copied and sold around the world.

Airlines fly their planes abroad for maintenance and repair, as it is cheaper and reduces costs.

The majority of these goods are manufactured in several provinces in China. It has become the major industry 
and chief employer of the populace in these areas, with little control by the central government. In effect, there are no national boundaries to lay down the law [13].

To combat this problem, more public awareness is needed via television programs to caution consumers about the products they purchase. More resources are needed to provide customs inspectors with the ability to monitor the import of counterfeit goods. This speaks to the mantra of buying cheap goods and wanting the safety net without the taxes.

\section{Conclusions-Collecting and Connecting the Dots}

This essay depicts a correlation between historical policies and current events/practices that are continuing to undermine public policies designed to benefit the consumer. The question, therefore, is, "Should we consumers and taxpayers allow this to continue?” As a quiet consumer advocate, I press for changing the political system to minimize the risks that apply to our health and safety.

George Lakoff in "The Little Blue Book" defines the mission of government as to protect and empower all of the populace on an equal basis through the use of the public (commons) [12]. This is characterized as resources for the betterment of all, and politics is about working for and representing people and concerns of citizens' everyday life. This certainly is not the current case of the government in Washington DC.

We are a consumptive society. As such, we are dependent upon producers to provide the products and services necessary to maintain our daily living requirements.

I have used three specific examples in the areas of food production, health care, and counterfeiting goods, making a case for a specific role of government. I have presented information and data that speak to problems, policy debates, and progress in the areas depicted. However, in today's political climate we find the government (politicians corrupted by the system) in Washington DC in gridlock. The nation has become polarized along ideological beliefs.

Mark Leibovich in his book "This Town" refers to Washington as "The Gilded Capital [7]." Most emphatically, the central theme of the book depicts the incestuous relationships among law firms, politicians, media, and lobbying firms in the capital. Bill Moyers, in his summation of his interview with Mr. Leibovich regarding his book, offered the following observations, "We are close to losing our democracy to the mercenary class, as a result of the predators in our capital who are close to monopolizing control of the government." He further states, "They have bought a political system, making change from within impossible. The plutocracy gets tax breaks, loopholes in legislation, and is awarded contracts. They fix the system so multinationals, hedge fund managers, and private equity firms pay a lower tax rate than the average worker does. They get subsidies. Rich corporate firms and banks are bailed out by taxpayers when they get into trouble. They fight regulation (Dodd/Frank Bill), prolong tax havens for multinationals, and stick it to consumers as we pay at the pump and the grocery store. Additionally, we pay the taxes they write off." Is it any wonder why the government is referred to as "The Wall Street Government [6].”

What is at stake in the scenario described in this essay is that the interests of corporate America are often at odds with the interests of consumers. At risk to what is at stake here is the air we breathe, the water we drink and the food we eat. This specifically relates to our health and safety, and we consumers are complicit in this scenario for our desire for cheap goods and immediate gratification.

I hope I have made the case for a specific role of government in our society, that we may begin to attack the corrupt political system by having term limits for all elected politicians, that we return to a citizenship government proposed by the founding fathers of the country, and that we eradicate campaign funding for special interests for the good of all concerned.

In researching and writing articles, the writer searches for facts to reaffirm his or her beliefs. We take parts of records and documents and develop an argument to defend our position. It is within this context that this essay is written.

I always want to enlighten and provoke thought for my readers.

\section{References}

[1] Circa (2000) Tufts University Global and Environmental Institute.

[2] Vance, P. (1960) The Waste Makers. IG Publishing, Brooklyn.

[3] Bedell, F. (2013) Consumerism in American Society and the Role of Government. Self Publication. 
www.delgpublishing.com

[4] Bacevich, A. (2008) The Limits of Power. Henry Holt and Company, LLC, NY.

[5] Friedman, T. (2013) Diet Coke Culture. New York Times, March.

[6] Bedell, F. (2013) Historical Illiteracy. Self Publication. www.delgpublishing.com

[7] Leibovich, M. (2014) This Town: Two Parties and a Funeral—Plus, Plenty of Valet Parking!-In America’s Gilded Capital. Penguin Group (USA) LLC, NY.

[8] Link TV (2012) Interview with Dave Bollier. This Land Is Our Land.

[9] (2013) Interview with Robert Kennedy III. Tavis Smiley Telecast.

[10] (2012) Citizens United Act. The Nation Magazine.

[11] Moyers, B. (2012) TV Journal Telecast. ALEC.

[12] Lakoff, G. (2013) The Little Blue Book: The Essential Guide to Thinking and Talking Democratic. Simon and Schuster, New York.

[13] Wikipedia.

[14] Moyers, B. (2013) TV Journal Telecast, Interview with Wendell Berry.

[15] Bachelder, K. (2014) Meet Mr. Franken Food. Wall Street Journal, 5-6 July 2014.

[16] Taylor, J. and Stites, J.D. (2014) Health Care Reform: From Truman to Obama. Becker’s Hospital Review, 11 February 2014.

[17] Gilbert, D. (2013) Getting Ready for the Affordable Health Act. Arizona Republic, September 2013.

[18] Moyers, B. (2013) TV Journal Telecast, Interview with Heather Gergen.

[19] McGinty, J.C. (2014) For Health Law’s Vitals, Look beyond Sign-Up. Wall Street Journal, 4 July 2014.

[20] Bustillos, M. (2014) Easy Chair-Fill in the Gaps. Harper Magazine, May 2014.

[21] Davidson, A. (2013) Who Is Betting on Obamacare. New York Times Magazine, 30 October 2013.

[22] Link TV (2014) Counterfeit Culture. 